\title{
HUBUNGAN ANTARA CAREER CAPITAL DAN WORK-LIFE BALANCE PADA KARYAWAN DI PT. PETROKIMIA GRESIK
}

\author{
IIma Iftahul Ula \\ Ika Rahma Susilawati \\ Selly Dian Widyasari \\ Program Studi Psikologi \\ Fakultas Ilmu Sosial dan Ilmu Politik \\ Universitas Brawijaya
}

\begin{abstract}
This study aimed to examine the correlation between career capital and worklife balance towards the employees of PT Petrokimia Gresik. The total sample was 102 official employees in the office of PT Petrokimia Gresik. Data were collected using simple random sampling technique; the career capital scale was based on Arthur and Inkson theory (2001), while the work-life balance scale was transadapted from Fisher's theory (2009). The itemtotal correlation coefficient was calculated using Product Moment Pearson and the reliability was examined using internal consistency technique. The result showed the Product Moment correlation $(r)$ was 0,522 with $p=0,000$, showing the positive linear correlation was at medium range between the two variables. This means, the higher the career capital of the employees, the higher their work-life balance. Otherwise, the lower career capital of the employees, the lower their work-life balance.
\end{abstract}

Keywords : Career Capital, Work-Life Balance

PSIKOISLAMIKA. Jurnal Psikologi Islam (JPI) copyright (c) 2015 Pusat Penelitan dan Layanan Psikologi. Volume 12 Nomor 1 Tahun 2015

\section{PENDAHULUAN}

Di era globalisasi seperti sekarang ini, setiap perusahaan yang ada sedang melakukan pengembangan secara signifikan baik dari kinerja maupun produktivitas. Setiap perusahaan melakukan hal tersebut dengan tujuan agar dapat bertahan dan bersaing dengan perusahaan-perusahaan lain. Hal ini menyebabkan tingginya tuntutan kerja yang harus dilakukan karyawan yang ada didalamnya sebagai motor penggerak perusahaan. Selain itu karyawan juga dituntut untuk terus meningkatkan kualitas yang dimiliki agar tetap dipekerjakan dan mampu bersaing didalam peningkatan karir pekerjaannya dikarenakan peningkatan karir merupakan salah satu tolak ukur keberhasilan karyawan dalam bekerja. Apabila berbicara mengenai karir, karir itu sendiri juga telah mengalami pengembangan model dan sifat dari para ahli. Adanya perubahan atau peningkatan karir karyawan didalam suatu perusahaan tidak lagi hanya ditentukan oleh wewenang atasan dan kebijakan organisasi itu sendiri, akan tetapi karyawan juga dapat berperan aktif dalam menentukan dan memilih karir yang diinginkan. Orang-orang yang mampu mengatur dirinya sendiri atau yang sering disebut dengan high-self management merupakan orang-orang yang sesuai berada di lingkungan organisasi yang semakin dituntut untuk lebih fleksibel dan lincah didalam era globalisasi seperti sekarang ini. High self-management lebih dimaksudkan pada keberadaan karir saat ini sudah tidak hanya ditentukan oleh organisasi semata, tetapi karyawan sendiri pun juga dapat menentukan arah karir yang sesuai dengan kemampuannya. Menurut Hall dan Moss (dalam 
Direnzo, 2010), di sini karyawan yang bertindak sebagai arsitek dari karir mereka masing-masing, bukan hanya atasan di dalam organisasi saja.

Adanya pembahasan mengenai high-self management membuat Arthur dan Inkson (2001) melakukan penelitian dan mengemukakan pemikiran baru tentang karir yang kemudian disebut dengan istilah career capital. Career capital adalah modal karir yang fokus pada kompetensi internal yang dimiliki individu untuk memilih dan mengembangkan jalur karir yang diinginkan sesuai dengan keterampilan dan minat individu (Arthur \& Inkson, 2001). Selain pembahasan tentang karir dan pengembangannya tersebut, ada hal lain yang dirasa perlu mendapatkan perhatian. Tingginya daya saing untuk meningkatkan modal karir dapat membuat individu menghabiskan lebih dari sepertiga waktunya dalam sehari untuk bekerja. Padahal setiap individu juga membutuhkan adanya waktu dan perhatian untuk kehidupan pribadinya. Setiap individu pasti menginginkan agar keduanya berjalan dengan baik. Banyak karyawan yang memiliki keinginan untuk mencapai keseimbangan antara karir dan kehidupan pribadi (Lazarova, 2004). Menurut Frone (dalam Colakoglu, 2005), keseimbangan kehidupan kerja atau work-life balance itu sendiri didefinisikan sebagai kurangnya konflik atau gangguan antara peran kerja dan non kerja (misalnya dengan pasangan, orang tua, dan anggota masyarakat).

TrueCareers pernah membuat survei tentang keseimbangan kehidupan kerja yang dilakukan pada tahun 2002. Hasil yang diperoleh $70 \%$ dari 1.500 responden mengatakan mereka tidak memiliki keseimbangan yang sehat antara kehidupan pribadi dan pekerjaan mereka (Lockwood, 2003). Penelitian dari The Women's Federation (Kong, 2013), sebuah survei di China juga menunjukkan lebih dari $64 \%$ karyawan di bawah usia 35 tahun mengalami tiga tekanan utama, yaitu konflik keseimbangan kehidupan kerja, tekanan sekolah, dan tekanan kompetitif. Dari hasil beberapa penelitian tersebut apabila ditarik kesimpulan individu saat ini mengalami kesulitan untuk menyeimbangkan antara kehidupan kerja dan kehidupan pribadi (Shortland \& Cummins, 2007). Apabila topik mengenai work-life balance tersebut dihubungkan dengan pembahasan tentang pengembangan karir yang lebih spesifik yaitu career capital maka akan memberikan kesimpulan yang berbeda. Perbedaan tersebut terlihat pada penelitian yang dilakukan Direnzo (2010) dengan judul An Examination of the Roles of Protean Career Orientation and Career Capital on Work and
Life Outcomes. Penelitian ini memberi kesimpulan bahwa work-life balance berhubungan positif dengan career capital. Akan tetapi yang membedakan penelitian Direnzo (2010) dengan penelitian yang dilakukan oleh peneliti terletak pada perbedaan dimensi career capital yang digunakan. Tesis dari Direnzo (2010) menggunakan dimensi career capital yang dikemukakan Luthans dan Youssef (2004) yang terdiri atas 3 dimensi yaitu dimensi psychological capital, human capital dan social capital sebagai dimensi career capital. Sementara penelitian ini menggunakan dimensi career capital yang dikemukakan oleh Arthur dan Inkson (2001) yang terdiri atas 3 dimensi yaitu dimensi knowing why, knowing how dan knowing whom sebagai dimensi career capital. Penelitian dari Direnzo (2010) juga menemukan jika tidak semua aspek dalam career capital berhubungan secara signifikan dengan worklife balance. Direnzo (2010) menarik kesimpulan bahwa sisi psikologis atau sisi internal seseoranglah yang paling berpengaruh untuk dapat mewujudkan work-life balance itu sendiri. Berdasarkan hal tersebut, peneliti ingin mengetahui apakah career capital berhubungan dengan work-life balance atau tidak dengan menggunakan dimensi career capital yang dikemukakan oleh (Arthur \& Inkson, 2001).

\section{KAJIAN PUSTAKA \\ Career Capital}

Career atau karir yang menurut Mathis dan Jackson (dalam Soejono, 2007) diartikan sebagai rangkaian posisi yang berkaitan dengan kerja yang ditempati individu sepanjang hidupnya. Sementara capital adalah modal. Sehingga apabila digabungkan career capital lebih dimaksudkan sebagai modal karir yang fokus pada kompetensi-kompetensi internal yang dimiliki individu untuk memilih dan mengembangkan jalur karir yang diinginkan sesuai dengan keterampilan dan minat individu (Arthur \& Inkson, 2001).

Menurut Arthur dan Inkson (2001), career capital memiliki beberapa dimensi yang dapat digunakan sebagai prediktor keberhasilan. Dimensi yang terdapat dalam career capital yaitu :

\section{a. Knowing Why}

Aspek ini merupakan kompetensi yang berhubungan dengan energi dari dalam diri individu, tujuan, motivasi dan pemahaman personal dengan dunia kerja yang dimiliki individu untuk mengejar karir yang diinginkan (Arthur \& Inkson, 2001). Dimensi knowing why memiliki 4 indikator yaitu energi dari dalam diri individu, memiliki 
tujuan untuk berhasil, memiliki motivasi dan pemahaman personal dengan dunia kerja dan karir (Arthur \& Inkson, 2001).

\section{b. Knowing How}

Kompetensi ini menitikberatkan pada keterampilan, keahlian dan pengetahuan yang diperoleh dari waktu ke waktu yang dapat menunjang karir individu (Arthur \& Inkson, 2001). Dimensi knowing how memiliki 3 indikator yaitu keterampilan, keahlian dan pengetahuan yang diperoleh dari waktu ke waktu (Arthur \& Inkson, 2001).

\section{c. Knowing Whom}

Aspek ini mencerminkan kompetensi karir yang berkaitan dengan jaringan sosial, hubungan internal maupun eksternal dan segala hal yang melibatkan orang-orang yang berpengaruh dalam pengembangan karir (Arthur \& Inkson, 2001). Dimensi knowing whom memiliki 5 indikator yaitu penerimaan sosial, hubungan internal dan eksternal, reputasi, sumber informasi dan kewajiban individu untuk saling berkumpul (Arthur \& Inkson, 2001).

\section{Work-Life Balance}

Menurut Greenhaus, Collins, dan Shaw (2002), balance pada umumnya dipandang sebagai tidak adanya konflik. Tetapi apabila dihubungkan dan dimasukkan kedalam pengertian work-life balance, keseimbangan atau balance disini berasal dari efektivitas (berfungsi baik, produktif, sukses) dan dampak positif (memuaskan, bahagia) baik untuk pekerjaan ataupun peran keluarga (Direnzo, 2010). Apabila didefinisikan secara keseluruhan, worklife balance adalah sejauh mana individu terlibat dan sama-sama merasa puas dalam hal waktu dan keterlibatan psikologis dengan peran mereka didalam kehidupan kerja dan kehidupan pribadi (misalnya dengan pasangan, orang tua, keluarga, teman dan anggota masyarakat) serta tidak adanya konflik diantara kedua peran tersebut. Dapat dikatakan individu yang memperhatikan antara keseimbangan kehidupan kerja dan kehidupan pribadi merupakan individu yang lebih mementingkan kesejahteraan psikologisnya daripada mengejar kekayaan semata (Westman, Brough, \& Kalliath, 2009).

Menurut Fisher (dalam Novelia, 2013) work-life balance merupakan stressor kerja yang meliputi empat komponen penting, yaitu : a. Waktu, meliputi banyaknya waktu yang digunakan untuk bekerja dibandingkan dengan waktu yang digunakan untuk aktivitas lain di luar kerja.

b. Perilaku, meliputi adanya tindakan untuk mencapai tujuan yang diinginkan. Hal ini berdasarkan pada keyakinan seseorang bahwa ia mampu mencapai apa yang ia inginkan dalam pekerjaannya dan tujuan pribadinya.

c. Ketegangan (strain), meliputi kecemasan, tekanan, kehilangan aktivitas penting pribadi dan sulit mempertahankan atensi.

d. Energi, meliputi energi yang digunakan untuk mencapai tujuan yang diharapkan. Energi merupakan sumber terbatas dalam diri manusia sehingga apabila individu kekurangan energi untuk melakukan aktivitas, maka dapat meningkatkan stress.

Fisher, Bulger, dan Smith (2009) juga mengatakan jika work-life balance memiliki 4 dimensi pembentuk, yaitu :

a. WIPL (Work Interference With Personal Life)

Dimensi ini mengacu pada sejauh mana pekerjaan dapat mengganggu kehidupan pribadi individu. Misalnya, bekerja dapat membuat seseorang sulit mengatur waktu untuk kehidupan pribadinya.

b. PLIW (Personal Life Interference With Work)

Dimensi ini mengacu pada sejauh mana kehidupan pribadi individu mengganggu kehidupan pekerjaannya. Misalnya, apabila individu memiiliki masalah didalam kehidupan pribadinya, hal ini dapat mengganggu kinerja individu pada saat bekerja.

c. PLEW (Personal Life Enhancement Of Work) Dimensi ini mengacu pada sejauh mana kehidupan pribadi seseorang dapat meningkatkan performa individu dalam dunia kerja. Misalnya, apabila individu merasa senang dikarenakan kehidupan pribadinya menyenangkan maka hal ini dapat membuat suasana hati individu pada saat bekerja menjadi menyenangkan.

d. WEPL (Work Enhancement Of Personal Life) Dimensi ini mengacu pada sejauh mana pekerjaan dapat meningkatkan kualitas kehidupan pribadi individu. Misalnya keterampilan yang diperoleh individu pada saat bekerja, memungkinkan individu untuk memanfaatkan keterampilan tersebut dalam kehidupan sehari-hari. 
Menurut Schabracq, Winnubst, dan Coope (dalam Novelia, 2013) ada beberapa faktor yang mungkin saja mempengaruhi work-life balance seseorang, yaitu :

a. Karakteritik Kepribadian

Karakteristik kepribadian berpengaruh terhadap kehidupan kerja dan di luar kerja. Menurut Summer dan Knight (dalam Novelia, 2013) terdapat hubungan antara tipe attachment yang didapatkan individu ketika masih kecil dengan work-life balance. la menyatakan bahwa individu yang memiliki secure attachment cenderung mengalami positive spillover dibandingkan individu yang memiliki insecure attachment.

a. Karakteristik Keluarga

Karakteristik keluarga menjadi salah satu aspek penting yang dapat menentukan ada tidaknya konflik antara pekerjaan dan kehidupan pribadi. Misalnya konflik peran dan ambiguitas peran dalam keluarga dapat mempengaruhi workfamily conflict.

b. Karakteristik Pekerjaan

ola kerja, beban kerja dan jumlah waktu yang digunakan untuk bekerja dapat memicu adanya konflik baik konflik dalam pekerjaan maupun konflik dalam kehidupan pribadi. Menurut Valcour (dalam Novelia, 2013) jumlah jam kerja akan mempengaruhi kepuasan seseorang akan keseimbangan dalam kehidupan pekerjaan dan kehidupan pribadi.

c. Sikap

Sikap masing-masing individu merupakan salah satu faktor yang mempengaruhi work-life balance. Adanya pendapat bahwa sentralitas terhadap suatu domain tertentu dalam kehidupan individu, akan meningkatkan jumlah waktu dan usaha yang dihabiskan dalam domain tersebut. Hal ini membuat individu sulit untuk menyediakan waktu untuk domain yang lain (Greenhaus, Collins, \& Shaw, 2002).

Walaupun persepsi dan penilaian tentang work-life balance antar satu individu dengan individu yang lain bervariasi tetapi pada intinya apabila individu mencapai kepuasan dan keseimbangan antara pembagian waktu dan keterlibatan psikologis antar keduanya, maka individu tersebut dapat dikatakan memiliki work-life balance (Colakoglu, 2005). Sebaliknya, apabila individu mengalami ketidakpuasan serta tidak adanya keseimbangan pembagian waktu dan keterlibatan psikologis antar keduanya, maka individu tersebut dapat dikatakan tidak memiliki work-life balance (Colakoglu, 2005). Dari sini dapat disimpulkan jika kepuasan dan keseimbangan antara kehidupan kerja dan kehidupan pribadi dialami ketika individu mencapai tingkat yang diinginkan dari apa yang ia pikirkan mengenai work-life balance.

\section{METODE}

\section{Partisipan dan Desain Penelitian}

Partisipan dalam penelitian ini adalah karyawan yang bekerja di kantor PT. Petrokimia Gresik yang berstatus karyawan tetap dan memiliki jam kerja Normal Day (07.00-16.00 WIB) sebanyak 163 karyawan. Penelitian ini menggunakan desain penelitian kuantitatif. Teknik pemilihan sampel yaitu dengan menggunakan teknik simple random sampling.

\section{Alat Ukur}

Peneliti menggunakan 2 skala. Skala yang pertama merupakan skala career capital yang dibuat sendiri oleh peneliti dengan acuan dari teori yang dikemukakan oleh Arthur dan Inkson (2001). Dimensi-dimensi skala career capital meliputi knowing why, knowing how dan knowing whom. Skala yang kedua merupakan skala work-life balance yang ditransadaptasi dari Fisher (2009). Dimensi-dimensi skala work-life balance meliputi WIPL (Work Interference With Personal Life), PLIW (Personal Life Interference With Work), PLEW (Personal Life Enhancement Of Work) dan WEPL (Work Enhancement Of Personal Life). Kedua skala tersebut merupaka skala likert dimana pengujian alat ukur menggunakan try out terpakai. Uji validitas dilakukan dengan menggunakan validitas isi dan uji reliabilitas dengan menggunakan uji koefisien Cronbach Alpha. Hasil yang diperoleh untuk skala career capital memiliki koefisien alpha sebesar 0,92 (sangat tinggi). Sementara skala work-life balance memiliki koefisien alpha sebesar 0,84 (tinggi).

\section{Prosedur Penelitian}

Peneliti membuat skala career capital dan skala work-life balance. Sebelum penelitian dilakukan, peneliti memastikan terlebih dahulu skala yang akan digunakan dengan berkonsultasi terlebih dahulu kepada expert judgement untuk memastikan kesesuaian aitem yang digunakan dan tampilan skala. Expert judgement dalam hal ini adalah dosen pembimbing I dan dosen pembimbing II. 
Kemudian peneliti mencari perusahaan yang sesuai dengan kriteria penelitian dan kemudian memenuhi semua persyaratan perijinan penelitian skripsi dari perusahaan yang bersangkutan. Persyaratan yang harus dipenuhi antara lain seperti membuat proposal skripsi, meminta surat pengantar penelitian skripsi dari fakultas, mencari surat keterangan sehat dari rumah sakit, melakukan presentasi dengan pihak personalia terkait boleh atau tidaknya penelitian tersebut dilakukan di PT. Petrokimia Gresik, serta mengikuti kelas pembekalan sebagai syarat mendapatkan KIB (Kartu Identitas Bekerja) agar dapat melakukan penelitian di PT. Petrokimia Gresik.

Setelah semua persyaratan terpenuhi, penelitian mulai dilakukan di PT. Petrokimia Gresik dengan menyebarkan skala kepada sampel yang sudah ditentukan. Dalam penyebaran skala, peneliti menyebarkan skala tersebut secara perorangan. Peneliti harus menawarkan dan menjelaskan kepada setiap responden mengenai penelitian yang dilakukan agar responden tertarik untuk mengisi skala. Kemudian setiap hari peneliti harus memeriksa kembali apakah skala sudah terisi atau belum.

Setelah terkumpul 102 skala yang memenuhi syarat yang ditentukan sebelumnya, peneliti melakukan uji reliabilitas untuk mengetahui aitem yang gugur dan aitem yang tidak gugur. Terdapat 2 aitem yang gugur dari 43 aitem skala career capital dan tersisa 41 aitem dengan koefisien Cronbach Alpha sebesar 0,92 (sangat tinggi). Sementara untuk skala work-life balance terdapat 3 aitem yang gugur dari 17 aitem skala work-life balance dan tersisa 14 aitem dengan koefisien Cronbach Alpha sebesar 0,84 (tinggi). Kemudian analisis data yang digunakan peneliti adalah teknik analisis korelasi Product Moment Pearson. Peneliti juga menggunakan uji normalitas dan uji linieritas untuk mengetahui data terdistribusi normal atau tidak (Sarjono \& Julianita, 2011).
HASIL

\section{Uji Asumsi Klasik}

\section{A. Uji Normalitas}

Peneliti menggunakan uji normalitas parametric test One-Sample Kolmogrov-Smirnov. Hasil uji normalitas skala career capital didapatkan hasil sebesar 0,578 dan skala work-life balance didapatkan hasil sebesar 0,723 yang berarti data terdistribusi normal karena (asymp.Sig) $>0,05$. Berikut tabel hasil uji normalitas.

Tabel 1. Uji Normalitas

\begin{tabular}{llll}
\hline Variabel & $\begin{array}{l}\text { Kolmogorov- } \\
\text { Smirnov Z }\end{array}$ & $\begin{array}{l}\text { Asymp.Sig. } \\
\text { (2-Tailed) }\end{array}$ & Keterangan \\
\hline $\begin{array}{l}\text { Career } \\
\text { Capital }\end{array}$ & 0,578 & 0,779 & $\begin{array}{l}\text { Distribusi } \\
\text { Normal }\end{array}$ \\
\hline $\begin{array}{l}\text { Work-Life } \\
\text { Balance }\end{array}$ & 0,723 & 0,693 & $\begin{array}{l}\text { Distribusi } \\
\text { Normal }\end{array}$
\end{tabular}

Sumber : diolah oleh peneliti

\section{B. Uji Linieritas}

Hasil dari pengujian linieritas pada kedua variabel dalam penelitian ini didapatkan hasil pada kolom Sig. Deviation from linearity sebesar 0,000 yang berarti lebih kecil dari 0,05. Berikut tabel hasil uji linieritas.

Tabel 2. Uji Linieritas

\begin{tabular}{|c|c|c|c|}
\hline Variabel & Signifikansi & $\begin{array}{l}\text { Linearity } \\
\text { (F) }\end{array}$ & Keterangan \\
\hline $\begin{array}{l}\text { Career } \\
\text { capital*work- } \\
\text { life balance }\end{array}$ & 0,000 & 36,844 & Linier \\
\hline
\end{tabular}

Sumber : diolah oleh peneliti

Hal tersebut menunjukkan bahwa variabel career capital memiliki hubungan linier positif dengan variabel work-life balance.

\section{Uji Hipotesis}

Hasil dari uji hipotesis dengan menggunakan teknik analisis korelasi Product Moment Pearson diperoleh hasil sebagai berikut.

Tabel 3. Uji Hipotesis

\begin{tabular}{llllll}
\hline \multicolumn{1}{c}{ Variabel } & $\begin{array}{c}\text { Koefisien } \\
\text { Korelasi }(r)\end{array}$ & $\begin{array}{c}\text { Koefisien Determinan } \\
\left(r^{2}\right)\end{array}$ & Signifikansi & Keterangan & $\begin{array}{l}\text { Sumbangan } \\
\text { Efektif }\end{array}$ \\
\hline & & & 0,000 & $\begin{array}{l}\text { Signifikan } \\
\text { (sedang) }\end{array}$ & $27,3 \%$ \\
$\begin{array}{l}\text { Career capital*Work Life } \\
\text { Balance }\end{array}$ & 0,522 & 0,2725 & &
\end{tabular}

Sumber : diolah oleh peneliti 
Hasil penelitian menunjukkan bahwa $r=0,522$ dengan signifikansi $(p)=0,000$. Hal ini berarti ada hubungan positif yang signifikan berada pada rentang sedang antara career capital dan worklife balance, dimana semakin tinggi nilai career capital maka semakin tinggi pula nilai work-life balance. Begitu pula sebaliknya, semakin rendah nilai career capital maka semakin rendah pula nilai work-life balance.

Nilai $r^{2}$ (koefisien determinan) $=0,273$ menunjukkan sumbangan efektif career capital terhadap work-life balance sebesar $27,3 \%$ sedangan sisanya $72,7 \%$ dipengaruhi oleh faktor lain yang tidak terdapat pada penelitian ini.

\section{DISKUSI}

Hasil yang diperoleh sesuai dengan hipotesis yang diajukan peneliti yaitu ada hubungan antara career capital dan work-life balance pada karyawan di PT. Petrokimia Gresik, sehingga dapat dikatakan Ha diterima. Pengujian hipotesis menunjukkan bahwa terdapat hubungan antara career capital dan work-life balance, dengan angka koefisien korelasi sebesar 0,522 dengan nilai signifikansi 0,000 . Nilai korelasi tersebut menunjukkan angka positif dan berada pada rentang sedang dengan angka koefisien korelasi sebesar 0,522. Sehingga dapat dikatakan kedua variabel memiliki hubungan linier positif dalam rentang sedang dalam artian jika career capital yang ada pada karyawan tinggi maka akan tinggi pula work-life balance yang dimiliki karyawan. Deskripsi data juga menunjukkan dimana mayoritas karyawan masuk dalam kategori career capital dan work-life balance sedang.

Apabila dianalisis dari kedua definisi variabel, indikator pembentuk dan kemudian dilakukan penelitian di kantor PT. Petrokimia Gresik, ternyata kedua variabel tersebut berhubungan linier positif. Jika dijabarkan, knowing why, knowing how dan knowing whom merupakan tiga dimensi pembentuk variabel career capital dimana ketiga dimensi tersebut memiliki masing-masing indikator pembentuk didalamnya. Karyawan dengan knowing why tinggi merupakan karyawan yang memiliki energi dan motivasi dari dalam diri untuk mencurahkan lebih banyak usaha dalam mencapai tujuan karir yang diinginkan. Tetapi energi dan motivasi tersebut masih berada dalam batas yang realistis dengan tetap memiliki pemahaman personal dengan dunia kerja dan karirnya sehingga individu mengetahui kekuatan dan kelemahan mereka (Kong, 2013).
Apabila dilihat, aspek knowing why ini merupakan aspek yang keberadaannya mendukung empat komponen penting yang mempengaruhi work-life balance. Aspek pertama mengenai waktu, karyawan yang memiliki knowing why yang baik akan sangat memahami bagaimana bersikap realistis dengan dunia kerjanya sehingga tetap dapat membagi waktu untuk bekerja dan kehidupan pribadi. Aspek kedua mengenai perilaku untuk mencapai tujuan yang diinginkan baik dalam pekerjaan maupun kehidupan pribadi. Hal ini sejalan dengan indikator knowing why yang juga memiliki tujuan untuk berhasil dalam berkarir tetapi tetap masih dalam batas realistis. Aspek ketiga meliputi ketegangan (strain) yang dapat mempengaruhi work-life balance juga dapat diminimalisir apabila individu memiliki pemahaman internal yang baik dengan pekerjaannya. Aspek terakhir yaitu energi untuk mencapai tujuan yang diharapkan ini sesuai dengan salah satu indikator knowing-why, sehingga dapat disimpulkan karyawan yang memiliki energi untuk mencapai tujuan yang diharapkan ini tidak hanya tujuan didalam pekerjaan tetapi juga tujuan didalam kehidupan pribadinya.

Dimensi career capital berikutnya yaitu knowing how yang menitikberatkan pada kompetensi-kompetensi yang dimiliki meliputi keterampilan, keahlian dan pengetahuan yang diperoleh dari waktu ke waktu yang dapat menunjang karir individu (Arthur \& Inkson, 2001). Dimensi ini sangat penting karena karyawan yang memiliki knowing how yang baik merupakan sumber daya yang sangat dihargai dan dibutuhkan dalam lingkungan yang kompetitif untuk melihat keberhasilan sebuah pekerjaan. Apabila dianalisis, dimensi ini berhubungan dengan salah satu dimensi work-life balance yaitu WEPL (Work Enhancement of Personal Life) yang berarti pekerjaan dapat meningkatkan kualitas kehidupan pribadi individu. Dengan kompetensi dan kemampuan yang dimiliki individu dari pekerjaan yang dilakukan, memungkinkan individu untuk memanfaatkan kemampuan tersebut dalam kehidupan sehari-hari, seperti misalnya kemampuan berkomunikasi, mengemukakan pendapat dan keterampilan-keterampilan lain yang dapat dimanfaatkan didalam kehidupan pribadi.

Selanjutnya aspek ketiga dari dimensi career capital yang tak kalah pentingnya berhubungan dengan work-life balance yaitu dimensi knowing whom. Dimensi ini berkaitan dengan jaringan sosial, hubungan internal maupun eksternal dan segala hal yang melibatkan orang-orang yang berpengaruh dalam pengembangan karir (Arthur 
\& Inkson, 2001). Hubungan yang dimaksud yaitu hubungan yang dapat mendukung pekerjaan selain dengan karyawan dan orang-orang profesional di perusahaan, juga hubungan dengan keluarga dan teman-teman diluar pekerjaan. Adanya penerimaan sosial yang baik akan memberikan hubungan internal dan eksternal yang baik pula. Hal ini dipercaya dapat meningkatkan reputasi dari karyawan itu sendiri didalam pekerjaannya. Tidak hanya rekanrekan kerja, tetapi keluarga dan teman di luar pekerjaan juga merupakan agen penting sebagai sumber pertukaran informasi dan motivasi dalam hal kemajuan karir.

Selanjutnya, dimensi knowing whom dalam career capital ini berhubungan dengan dimensi work-life balance PLEW (Personal Life Enhancement of Work) dimana keberadaan orang-orang didalam kehidupan pribadi dapat meningkatkan performa individu dalam dunia kerja. Adanya knowing how yang baik dalam diri individu juga mempengaruhi berkurangnya WIPL (Work Interference With Personal Life) yang menitikberatkan pada pekerjaan mengganggu kehidupan pribadi dan PLIW (Personal Life Interference With Work) yang menitikbertakan pada kehidupan pribadi mengganggu pekerjaan. Jadi, karyawan yang memiliki knowing whom, akan kecenderungan memiliki work-life balance karena ia merupakan individu yang memiliki hubungan baik dengan rekan kerja maupun orang-orang diluar pekerjaannya.

Berdasarkan penjelasan di atas, individu yang memiliki work-life balance yang baik merupakan individu yang mampu mengelola semua aspek yang ada didalam kehidupannya. Individu yang memiliki career capital yang tinggi adalah individu yang memiliki modal psikologis, modal kompetensi dan modal sosial yang baik untuk mampu menciptakan keseimbangan antara pekerjaan dan kehidupan pribadinya. Individu seperti itu merupakan individu yang memiliki tujuan dan harapan yang realistis tentang bagaimana terlibat secara efektif dalam setiap peran yang dilakukan baik sebagai karyawan maupun perannya didalam kehidupan pribadi. Selain itu individu seperti itu merupakan individu yang sangat berharga dan diminati di lingkungan kerja karena dengan kompetensi dan pengalaman yang dimilikinya memungkinkan individu untuk menyelesaikan pekerjaan mereka dengan lebih efisien dan memiliki lebih banyak waktu untuk kehidupan pribadi. Terakhir, individu dengan karakteristik seperti itu merupakan individu yang dapat memanfaatkan jaringan sosial yang dimiliki untuk mencari informasi terkait karir didalam pekerjaan. Adanya jaringan sosial juga dapat memberikan dukungan tidak hanya sekedar dukungan dalam pekerjaan tetapi juga dukungan dalam keharmonisan kehidupan pribadi.

Nilai $r^{2}$ (koefisien determinan) $=27,3 \%$ menunjukkan sumbangan efektif hubungan career capital terhadap work-life balance sebesar 27,3\% pada karyawan PT. Petrokimia Gresik. Sedangkan sisanya $72,7 \%$ dipengaruhi oleh faktor lain yang tidak terdapat pada penelitian ini. Adapun faktor lain yang dapat mempengaruhi work-life balance karyawan menurut Schabracq, Winnubst, dan Coope (dalam Novelia, 2013) yang pertama berasal dari karakteristik kepribadian masing-masing karyawan. Setiap karyawan pasti memiliki perbedaan kadar penerimaan dalam menerima keadaan dirinya sendiri dan lingkungan sekitar. Ditambah dengan bervariasinya pandangan setiap karyawan mengenai seimbang atau tidak seimbangnya kehidupan kerja dan kehidupan pribadinya. Biasanya individu yang memiliki penerimaan diri dan pandangan yang positif dengan rutinitas pekerjaan dan kehidupan pribadinya cenderung memiliki work-life balance yang lebih tinggi dibanding individu yang kurang memiliki penerimaan diri dan pandangan yang positif dengan rutinitas pekerjaan dan kehidupan pribadi yang dijalaninya.

Faktor berikutnya yang mempengaruhi worklife balance menurut Schabracq, Winnubst, dan Coope (dalam Novelia, 2013) yaitu perbedaan karakteristik keluarga dimana setiap karyawan memiliki cara yang berbeda dalam membentuk dan membina keluarga itu sendiri. Misalnya saja peran ibu dan ayah dalam setiap keluarga memiliki porsi yang berbeda. Ada ayah yang memiliki peran untuk membantu ibu menyelesaikan pekerjaan rumah dan membantu mengasuh anak, tetapi ada juga ayah yang tidak berperan untuk membantu tugas ibu di rumah. Hal-hal seperti ini dapat menciptakan perbedaan tugas dan tanggung jawab di rumah yang dapat mempengaruhi pandangan setiap karyawan dalam menyikapi work-life balance itu sendiri (Novelia, 2013).

Faktor ketiga yang mempengaruhi work-life balance menurut Schabracq, Winnubst, dan Coope (dalam Novelia, 2013) yaitu perbedaan karakteristik pekerjaan. Setiap karyawan pasti memiliki perbedaan dalam pola kerja, beban kerja, jumlah jam kerja sampai pada perbedaan resiko adanya konflik kerja. Perbedaan tersebut juga dikarenakan ketidaksamaan level tugas dalam setiap jabatan yang dimiliki 
karyawan (Novelia, 2013). Apalagi skala disebar ke semua lini jabatan sehingga pandangan akan beban kerja itu sendiri menjadi bervariasi.

Faktor keempat yang mempengaruhi work-life balance menurut Schabracq, Winnubst, dan Coope (dalam Novelia, 2013) yaitu perbedaan sikap dari masing-masing karyawan dalam melihat work-life balance itu sendiri. Perbedaan mengenai skala prioritas hidup juga membuat karyawan memiliki pandangan yang berbeda mengenai work-life balance. Ada karyawan yang memiliki sikap untuk mementingkan pekerjaan diatas segalanya hingga ia menomorduakan kehidupan pribadinya. Ada juga karyawan yang mementingkan kehidupan pribadi sehingga ia hanya bekerja secara formalitas dan sekedarnya saja tanpa memiliki planning lebih dalam berkarir. Tetapi ada juga karyawan yang memiliki sikap untuk mementingkan keduanya karena keduanya merupakan bagian dari tanggung jawab hidup atau ada pula karyawan yang tidak mementingkan keduanya sama sekali. Semua tergantung dari cara menyikapi masing-masing karyawan (Novelia, 2013).

Ada juga faktor tambahan seperti perbedaan gender yang dapat mempengaruhi hasil penelitian. Kemudian dari hasil Uji T-Test dengan menggunakan SPSS for Windows versi 20.00 diperoleh kesimpulan bahwa baik career capital maupun work-life balance pada perempuan lebih positif dibandingkan career capital dan work-life balance pada laki-laki. Hal ini sesuai dengan penelitian yang dilakukan oleh (Niharika Doble, 2010) yang berjudul Gender Differences in the Perception of Work-Life Balance yang mengatakan bahwa laki-laki merasa lebih puas ketika mereka memiliki pencapaian dalam hal pekerjaan, tetapi perempuan menekankan bahwa pekerjaan dan keluarga keduanya samasama penting dan keduanya merupakan sumber kepuasan mereka. Mereka memiliki batas-batas yang ketat antara pekerjaan dan keluarga. Mereka tidak menyukai jika keduanya saling mengganggu (Niharika Doble, 2010).

Peneliti juga menggunakan Uji Regresi Linier Sederhana untuk menguji pengaruh variabel bebas (career capital) terhadap variabel terikat (worklife balance). Peneliti juga mencoba untuk melihat apakah ada perbedaan apabila variabel career capital yang awalnya merupakan variabel bebas diletakkan menjadi variabel terikat, dan variabel work-life balance yang awalnya merupakan variabel terikat diletakkan menjadi variabel bebas. Hasil yang didapat ternyata variabel career capital mempengaruhi secara signifikan terhadap variabel keseimbangan kehidupan kerja atau work-life balance. Begitu juga sebaliknya variabel work-life balance mempengaruhi secara signifikan terhadap variabel career capital.

Peneliti menambahkan Uji Regresi Linier Berganda untuk melihat pengaruh dimensi variabel career capital terhadap dimensi variabel work-life balance. Hasil yang diperoleh menunjukkan jika dimensi knowing whom (X3) pada variabel career capital memberikan pengaruh yang signifikan terhadap variabel work-life balance. Begitu juga untuk dimensi PLIW (Personal Life Interference with Work) (Y2) dan PLEW (Personal Life Enhancement of Work) (Y4) pada variabel work-life balance memberikan pengaruh yang signifikan terhadap variabel career capital.

Apabila dianalisis, hal ini juga dipengaruhi oleh karakteristik perusahaan yang menjadi tempat penelitian. Karakteristik BUMN yang bersifat konvensional dimana karyawan cenderung untuk bekerja sesuai rutinitas dengan beban kerja yang tergolong sedang membuat karyawan yang ada di dalamnya cenderung memiliki keseimbangan kehidupan kerja dan kehidupan pribadi atau worklife balance yang tinggi. Selain itu pola kerja yang bersifat kolektif yang cenderung menyelesaikan tugas secara bersama-sama menjadi faktor dimensi knowing whom atau dimensi yang menitikberatkan peningkatan karir dipengaruhi oleh hubungan sosial menjadi faktor yang signifikan dalam mempengaruhi career capital pada karyawan di perusahaan tersebut daripada faktor internal seperti motivasi (knowing why) dan kemampuan (knowing how) yang dimiliki masing-masing karyawan. Kemudian untuk dimensi work-life balance, terbukti ternyata kehidupan pribadi yang lebih mempengaruhi pekerjaan. Penyebaran skala di kantor dengan karakteristik pekerjaan bersifat rutin memberikan hasil yang berbeda dimana karyawan yang ada didalamnya masih memprioritaskan kehidupan pribadi dan hubungan sosial. Mungkin akan berbeda hasilnya jika skala disebar di pabrik atau pekerjaan lapang yang mayoritas memiliki jam kerja shift dimana karyawan lebih memiliki tingkat kesulitan dalam membagi waktu dan perhatiannya untuk kehidupan pribadi.

\section{KESIMPULAN}

Hasil analisis korelasi Product Moment Pearson antara career capital dan work-life balance pada karyawan di PT. Petrokimia Gresik adalah $r=0,522$ 
dengan taraf signifikansi $=0,000$. Nilai korelasi tersebut berada pada rentang sedang dan menunjukkan angka positif, sehingga dapat dinyatakan kedua variabel memiliki hubungan linier positif dalam kategori sedang. Variabel career capital memiliki sumbangan efektif terhadap terciptanya work-life balance yaitu sebesar $27,3 \%$, sedangkan $72,7 \%$ lainnya dipengaruhi oleh faktor lain yang tidak diteliti dalam penelitian ini. Adapun faktor lain yang dapat mempengaruhi work-life balance karyawan menurut Schabracq, Winnubst, dan Coope (Novelia, 2013) yaitu berasal dari karakteristik kepribadian masing-masing karyawan dalam menerima keadaan dirinya sendiri dan lingkungan sekitar, perbedaan karakteristik keluarga, perbedaan karakteristik pekerjaan dan perbedaan sikap dari masing-masing karyawan dalam melihat work-life balance itu sendiri.

Mengenai hasil Uji T-Test untuk menguji apakah terdapat perbedaan career capital dan work-life balance antara laki-laki dan perempuan. Hasil yang diperoleh koefisien thitung career capital laki-laki sebesar 72,696 dan career capital perempuan sebesar 61,217 dengan koefisien $P$-value sebesar 0,000 dan lebih kecil dari 0,05 . Hasil tersebut menunjukkan terdapat perbedaan signifikan pada career capital ditinjau dari jenis kelamin. Sedangkan dari hasil nilai rata-rata career capital laki-laki sebesar 160,7432 dan nilai rata-rata career capital perempuan sebesar 166,5357 dapat disimpulkan jika career capital perempuan lebih tinggi dibandingkan career capital pada laki-laki. Untuk work-life balance antara laki-laki dan perempuan diperoleh koefisien t hitung work-life balance laki-laki sebesar 55,182 dan work-life balance perempuan sebesar 43,033 dengan koefisien $P$-value sebesar 0,000 dan lebih kecil dari 0,05 . Hasil tersebut menunjukkan terdapat perbedaan signifikan pada work-life balance ditinjau dari jenis kelamin. Sedangkan dari hasil nilai ratarata work-life balance laki-laki sebesar 53,0405 dan nilai rata-rata work-life balance perempuan sebesar 55,8214 dapat disimpulkan jika work-life balance perempuan lebih tinggi dibandingkan work-

\section{DAFTAR PUSTAKA}

Arthur, M. B., \& Inkson, K. (2001). How To Be a Succesful Career Capitalist. Organizational Dynamics, 48-61.

Colakoglu, S. N. (2005). The Relationship between

Career Boundarylessness and Individual life balance pada laki-laki. Terakhir, uji deskriptif menunjukkan bahwa career capital dan work-life balance terbaik berada pada rentang usia 41-50 tahun.

Berdasarkan hasil penelitian dan pembahasan yang telah diuraikan sebelumnya, maka peneliti memberikan beberapa saran yang diharapkan dapat bermanfaat bagi pihak lain. Beberapa saran yang dapat diberikan peneliti agar dapat lebih meningkatkan aspek career capital dan work-life balance sebaiknya dari pihak perusahaan dan karyawan secara bersama-sama lebih memperhatikan motivasi intrinsik agar karyawan memiliki tanggungjawab untuk terlibat dalam pekerjaannya dengan lebih baik. Perlu adanya sebuah kesadaran agar karyawan menjadikan pekerjaan sebagai sebuah rutinitas yang menyenangkan. Kedua, penataan ruang kerja yang nyaman, bersih, rapi dengan suasana kerja yang kondusif sebaiknya juga menjadi perhatian agar karyawan dapat bekerja dengan lebih nyaman dan menyenangkan. Selain itu atasan yang demokratis, bijaksana, adil dan dekat dengan para karyawannya akan membuat karyawan menjadi lebih nyaman dalam bekerja dan berkarir. Perubahan karakteristik organisasi dimana peningkatan karir tidak hanya ditentukan oleh organisasi saja, tetapi karyawan juga ikut berperan aktif dalam menentukan arah karir yang diinginkan berdasarkan kinerja yang dihasilkan agar karyawan dapat menjadi lebih termotivasi dalam bekerja

Bagi pihak-pihak yang berminat untuk melakukan penelitian sejenis atau berniat untuk mengembangkan penelitian ini lebih lanjut, sebaiknya perlu dilakukan pengembangan variabel serta faktor-faktor lain yang juga berpengaruh terhadap career capital dan work-life balance seperti perbedaan faktor gender, karakteristik kepribadian, karakteristik keluarga, karakteristik pekerjaan dan perbedaan sikap individu juga perlu dikaji lebih dalam lagi. Sebaiknya juga dilihat terlebih dahulu bagaimana karakteristik pola kerja di perusahaan atau tempat yang akan dijadikan sebagai tempat penelitian agar karakteristik subjek yang diambil dapat merepresentasikan apa yang sebenarnya ingin diteliti.

WellBeing: A Contingency Approach. Journal of Philosophy , 1-293.

Direnzo, M. S. (2010). An Examination of the Roles of Protean Career Orientation and Career Capital on Work and Life Outcomes. Journal of Philosophy , 1-215. 
Fisher, G. G., Bulger, C. A., \& Smith, C. S. (2009). Beyond Work and Family: A Measure of Work/ Nonwork Interference and Enhancement. Journal of Occupational Helath Psychology, 441-456.

Greenhaus, J. H., Collins, K. M., \& Shaw, J. D. (2002). The Relation Between Work-Family Balance and Quality. Journal of Vocational Behavior, 510-531.

Kong, H. (2013). Relationships Among Work-Family Supportive Supervisors, Career Competencies, and Job Involvement. International Journal of Hospitality Management , 304-309.

Lazarova, M. B. (2004). The Role Organizational Career Development Programs, Work/Life Balance Programs, and Commitment to Career and Personal Life for Retention of Professional Employees. Journal of Philosophy , 1-221.

Lockwood, N. R. (2003). Work/Life Balance Challenges and Solutions. USA: Society for Human Resource Management Research Department.
Niharika Doble, M. V. (2010). Gender Differences in the Perception of Work-Life Balance. Journal of Management , 331-342.

Novelia, P. (2013). Hubungan Antara Work-Life Balance dan Komitmen Berorganisasi Pada Pegawai Perempuan. 1-44.

Sarjono, H., \& Julianita, W. (2011). SPSS vs LISREL Sebuah Pengantar, Aplikasi untuk Riset. Jakarta: Salemba Empat.

Shortland, S., \& Cummins, S. (2007). Work-Life Balance: Expatriates Reflect the International Dimension. Global Business and Organizational Excellence, 28-42.

Soejono, F. (2007). Karir Dalam Organisasi Selular (Career In Celullar Organizations). Jurnal Manajemen , 1-14.

Westman, M., Brough, P., \& Kalliath, T. (2009). Expert Commentary on Work-Life Balance and Crossover of Emotions and Experiences: Theoritical and Practice Advancements. Journal of Organizational Behavior , 588-595. 